\title{
Alternative reproductive strategies: a queen perspective in ants
}

\author{
Jürgen Heinze and Laurent Keller
}

I thas recently become clear that there is tremendous variation in the structure of insect societies, especially in the number and identity of reproductive queens. Such variation is important because it affects the relatedness among colony members, and thus the indirect benefits workers gain by helping to raise the brood. Genetic studies show that a high queen number is usually associated with a low level of relatedness between colony members ${ }^{1-4}$. However, in many ant species there are significant differences between observed and expected relatedness.

Higher than expected relatedness might stem from high reproductive skew, with one or few of the queens monopolizing colony reproduction ${ }^{5}$ Lower than expected relatedness might in principle result from multiple mating by queens. However, according to genetic studies, the effective mating frequency of queens is low in most ant species and multiple mating is therefore unlikely to affect significantly the average relatedness between colony members ${ }^{6}$. Instead, lower than expected relatedness might be a consequence of significant turnover of queens within colonies (i.e. old queens being replaced by new ones). Here, we show that queen replacement is probably more common than has previously been acknowledged. We describe evidence that some queens take over established colonies instead of founding their own colonies, and discuss the consequences of this behavior on the kin structure of colonies. Furthermore, we investigate how this and other dependent reproductive tactics affect queen morphology and might be involved in the evolution of social parasitism. We do not discuss other reproductive tactics, such as thelytoky, reproduction by mated workers and male polymorphism, which are summarized in Box 1.

\section{Breeding structure versus genetic composition of colonies}

If colonies form closed breeding units and are stable over time, all workers should have genotypes compatible with those of the colonies' queens and their mates. However, genetic studies in polygynous (multiple-queen) ant colonies occasionally reveal genotypes of workers, new queens and males that are incompatible with those of the reproductive queens present in the colony at the time of nest collection ${ }^{7-9}$. This indicates that there has been recent queen turnover.

Queen turnover in polygynous colonies is not unexpected given the often short maximum lifespan of polygynous queens, which in some species can be less than one year ${ }^{10}$. Because workers often live longer ${ }^{11}$, a significant proportion of workers are expected to be present in the colony long after their mother's death, alongside the new queen or queens. In moderately polygynous species, nestmate queens are often close relatives, indicating that new queens are mostly recruited from within the colony ${ }^{1-4}$. However, in some species, unrelated queens might be adopted into a colony: evidence for this comes from nests that contain several different lineages of maternally inherited mitochondrial DNA ${ }^{12-14}$ (Table 1). Little is known about processes regulating recruitment of queens in polygynous colonies, and how often alien queens succeed in infiltrating a colony. Furthermore, it needs to be investigated whether the occurrence of these mixed polygynous colonies results from recognition mistakes made by either side or from an active invasive tactic of the queen.

The finding that monogynous (single-queen) colonies can contain workers from several matrilines is more surprising. In a few cases, the occurrence of several worker matrilines might be due to cooperative colony founding by queens, followed by the death of all but one queen ${ }^{15}$, but more frequently it seems to result from queen replacement ${ }^{16,17}$ (Table 1 ).

Commonly, it was assumed that monogynous colonies are doomed after the death of the mother queen ${ }^{18}$. However, genetic and observational studies indicate that young queens can sometimes take over established colonies under natural conditions. For example, in Leptothorax nylanderi, new queens can usurp colonies both with and without a queen when empty nest sites are scarce. Nestmate queens soon become intolerant of each other and one of them is eventually expelled from the nest ${ }^{17}$.

Mounting evidence indicates that such colony takeover in monogynous colonies, and adoption of unrelated queens in polygynous colonies are not rare phenomena of marginal importance but might occur frequently in ants (Table 1). This raises the questions of why queens sometimes infiltrate alien colonies instead of initiating a new colony, and why this is tolerated by the workers.

From the queen perspective, the best reproductive option depends on the relative probabilities of successfully initiating a new colony versus being accepted in an established colony. Mortality rates of queens during solitary colony founding are usually high because of the limitation of suitable nest sites, adverse climatic conditions or 
predation. Often, fewer than one queen in a thousand survives until the colony has reached a sufficient size to produce sexuals ${ }^{11,19}$. By successfully taking over an established colony, the young queen considerably increases her chance to reproduce. However, the queen first has to be accepted in the colony, and this depends on the behavior of the resident workers.

Workers in a queenless colony can usually increase their indirect fitness by adopting a new, related queen, and therefore are not expected to reject a young relative. By contrast, workers should accept a new unrelated queen only when the new queen's presence increases survival of the sexual brood already present in the colony ${ }^{1}$. This might occur in species where male and female sexuals have a developmental time longer than the average lifetime of the workers. For example, in the carpenter ant, Camponotus ligniperdus, larval development extends over more than the average adult lifespan of a worker. Therefore, queen replacement by unrelated queens might be favored by workers in orphaned colonies containing sexual brood ${ }^{16}$.

When the colony still contains a queen, workers should be less likely to accept a new queen - they should do so only when queens are related and when the presence of additional queens increases colony survival or productivity $^{4,20}$. However, workers never benefit from the replacement of their mother by an unrelated queen. The infiltration of queenright colonies by alien queens therefore amounts to intraspecific social parasitism ${ }^{17,21}$.

Little is known about the success of queens that infiltrate established colonies. In a monogynous population of the fire ant, Solenopsis geminata, as many as $35 \%$ of colonies

\section{Box 1. Reproductive tactics in ants ${ }^{a}$}

Monogyny: one single queen present per colony (many species of Atta, Leptothorax, Myrmecocystus and Pogonomyrmex)

Facultative polygyny: several fertile queens can be present per colony (many species of Formica, Leptothorax and Myrmica)

Functional monogyny: one of several queens per colony monopolizes reproduction (Leptothorax sp. A, Leptothorax gredler)

Oligogyny: several fertile queens can be present in different parts of nest due to mutual intolerance (Camponotus ligniperdus)

Monandry: queen singly mated (many species of Camponotus and Leptothorax) Polyandry: queen multiply mated (Acromyrmex spp.)

Gamergate: mated worker that lays fertilized eggs. Gamergates occur together with queens in some species (many species of Rhytidoponera) but completely replace them in others (Diacamma, Dinoponera)

Thelytoky: production of diploid offspring from unfertilized eggs (Cataglyphis cursor, Platythyrea punctata, Pristomyrmex pungens)

Ergatoid males: non-dispersing, wingless males engaging in copulation with female sexuals in the nest (Cardiocondyla, Hypoponera, Technomyrmex)

aBased on Refs 11,49

contained queens that entered the colony only after it had been founded by another queen ${ }^{19}$. It was estimated that queens attempting colony takeover had a slightly lower chance of succeeding than independently founding queens, and that workers received a similar investment-return from the production of either type of queen ${ }^{19}$.

\section{Alternative reproductive strategies and queen polymorphism}

In numerous animals, such as several species of mites or dung beetles, intraspecific variation in male reproductive

Table 1. Species in which some colonies have been found to contain unrelated matrilines ${ }^{a}$

\begin{tabular}{|c|c|c|c|c|c|}
\hline Species & $\begin{array}{l}\text { Proportion of } \\
\text { colonies with } \\
\text { multiple matrilines } \\
\text { (sample size) }\end{array}$ & Social structure & Suggested explanation & Methods & Refs \\
\hline
\end{tabular}

\section{Dolichoderinae}

Iridomyrmex purpureus $\quad 6.3 \%(16)$

$\begin{array}{cc}\text { Facultative polygyny } & \begin{array}{c}\text { Primary polygyny or adoption of mtDNA } \\ \text { unrelated queens }\end{array}\end{array}$

Formicinae

Camponotus ligniperdus $38 \%(21)$

Monogyny or
oligogynyb

Adoption of unrelated queens

Microsatellites, multilocus DNAfingerprints and field observations

\section{Myrmicinae}

Acromyrmex versicolor Leptothorax acervorum Leptothorax albipennis Leptothorax nylanderi

Solenopsis geminata

Solenopsis invicta (monogynous population, Florida) Solenopsis invicta (polygynous population, Georgia)

\section{Ponerinae}

Pachycondyla villosa $\quad 40 \%$ c (25) Rhytidoponera sp. $12 \quad 34.7 \%$ (75)
$56 \%$ c (64) $15 \%(27)$ $19-22 \%(224 ?)$ $7-9 \%(419)$ $35 \%(75)$ $3 \%(3372)$

$87 \%(92)$
Facultative polygyny Primary polygyny Facultative polygyny

Monogyny

Monogyny

Monogyny

Monogyny

Polygyny

Facultative polygyny

Facultative polygyny
Adoption of unrelated queens Egg dumping by parasite queens Adoption of unrelated queens Adoption of unrelated queens

Adoption of unrelated queens

Adoption of unrelated queens

mtDNA

Allozyme electrophoresis mtDNA

Allozyme analyses

Microsatellites and field observations Queen size

Diploid male production

aThe coexistence of unrelated individuals in an ant society might be due to the adoption of unrelated queens into polygynous colonies, queen replacement by unrelated queens in monogynous colonies, egg-dumping or primary polygyny without queen execution.

bCo-occurring queens are intolerant of each other.

cProportion of founding associations with unrelated queens among founding colonies; the proportion of mature colonies with unrelated queens is not known. 
Table 2. Ant genera that show pronounced intraspecific polymorphism of queens $s^{a, b}$

\begin{tabular}{|c|c|c|}
\hline Subfamily & Genus & Type of polymorphism \\
\hline Dolichoderinae & $\begin{array}{l}\text { Tapinoma } \\
\text { Technomyrmex }\end{array}$ & $\begin{array}{l}\text { Short versus long wings } \\
\text { Winged versus wingless }\end{array}$ \\
\hline Formicinae & $\begin{array}{l}\text { Camponotus } \\
\text { Formica } \\
\text { Polyrhachis }\end{array}$ & $\begin{array}{l}\text { Size } \\
\text { Size } \\
\text { Size }\end{array}$ \\
\hline Myrmeciinae & Myrmecia & $\begin{array}{l}\text { Short versus long wings; winged } \\
\text { versus wingless }\end{array}$ \\
\hline Myrmicinae & $\begin{array}{l}\text { Atta } \\
\text { Acromyrmex } \\
\text { Leptothorax } \\
\text { Megalomyrmex } \\
\text { Monomorium } \\
\text { Myrmica } \\
\text { Myrmecina } \\
\text { Pogonomyrmex } \\
\text { Solenopsis }\end{array}$ & $\begin{array}{l}\text { Size } \\
\text { Size } \\
\text { Size; winged versus wingless } \\
\text { Winged versus wingless } \\
\text { Short versus long wings; winged } \\
\text { versus wingless } \\
\text { Size } \\
\text { Winged versus wingless } \\
\text { Winged versus wingless } \\
\text { Size }\end{array}$ \\
\hline Ponerinae & $\begin{array}{l}\text { Pachycondyla } \\
\text { Ectatomma }\end{array}$ & $\begin{array}{l}\text { Winged versus wingless } \\
\text { Size }\end{array}$ \\
\hline Pseudomyrmecinae & $\begin{array}{l}\text { Pseudomyrmex } \\
\text { Tetraponera }\end{array}$ & $\begin{array}{l}\text { Size } \\
\text { Size }\end{array}$ \\
\hline
\end{tabular}

aData are taken from Refs 23 and 49.

bThe list does not contain social parasites, where morphologically different female reproductives presumably do not have different dispersal tactics, and species where both morphological queens and mated workers co-occur.

tactics is often associated with differences in their morphology22. A similar phenomenon seems to occur in ant queens $^{23}$. A bimodal distribution of queen size or the existence of two different queen morphs occurs in species from about $10 \%$ of all ant genera (Table 2; Fig. 1). However, direct evidence for an association of queen morphology and founding strategy is still scarce. Queens that start a new colony in isolation often completely rely on histolysed body tissue, fat reserves and storage proteins until the first workers eclose and begin to forage ${ }^{11}$. By contrast, young queens that seek adoption into established colonies do not need these large reserves and can therefore be smaller and lighter ${ }^{24}$. Queens that return to their maternal nests after mating, or those in a dense population that invade alien colonies, do not need wings and flight muscles for dispersal. For example, Solenopsis geminata queens specialized (a)

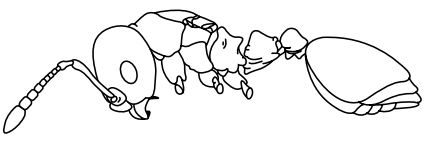

(b)

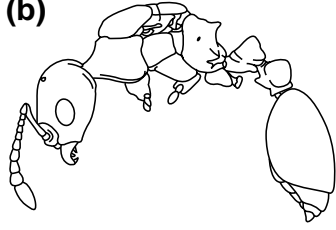

Fig. 1. Two queens of the parasitic ant, Leptothorax wilsoni, in lateral view, showing remarkably large variation in body size and thorax volume. (a) A wing-reduced queen with strongly reduced flight muscles. (b) A queen that initially had fully developed wings. Illustrations by Kathy BrownWing. Reproduced, with permission, from Ref. 50. for intraspecific parasitism are about three times lighter and contain less fat than independently founding queens ${ }^{19}$.

The degree of queen dimorphism ranges from young queens, all of which are winged and differ only in their fat content and weight (Solenopsis ${ }^{19}$ ), to the gradual reduction of wings and the complete loss of all structures associated with dispersal (some Monomorium ${ }^{25}$ and Leptothorax ${ }^{26}$ ). Little is known about the mechanisms that underlie the production of queens with different phenotypes. Wingless female reproductives of Technomyrmex albipes replace the originally winged queen after her death and thus are part of the regular life cycle of each colony ${ }^{27}$. This makes it unlikely that a genetic polymorphism is responsible for the different types of female reproductives. In other species, such as Myrmecina graminicola ${ }^{28}$, queens and their female sexual offspring tend to have a common phenotype, but whether this is due to a common genotype, a similar environment or maternal effects has not yet been clarified. Controlled breeding experiments indicate a genetic basis for the occurrence or absence of wings in Harpagoxenus sublaevis ${ }^{29}$ and Leptothorax sp. A (Ref. 26). A single genetic element has been shown to influence size, fat content, the rate of wing loss and the reproductive behavior of queens in the fire ant $S$. invicta ${ }^{30}$.

The simultaneous occurrence of both queen phenotypes over a large part of the range of several species suggests that queen polymorphism is not a transient phenomenon $^{23}$. A stable genetic queen polymorphism might be maintained by environmental heterogeneity (e.g. habitat patch $\operatorname{size}^{26}$ ) or frequency-dependent selection (e.g. the success of parasitic queens might depend on the frequency of solitarily founding queens).

In other species, the specialization of one queen genotype for dependent founding and, in particular, for intraspecific parasitism, might be an intermediate stage in the evolution of workerless social parasites ${ }^{3,31,32}$. The queens of more than 60 ant species obligatorily exploit the workforce of established colonies of related species to produce their own offspring, which normally consists only of sexuals ${ }^{11}$. It was suggested that a queen polymorphic species might evolve into a host-parasite species pair ${ }^{31,32}$. Both social parasites with miniaturized queens and species with a pronounced intraspecific queen polymorphism are rather common in the genera Myrmica and Leptothorax ${ }^{31,32}$ and, according to genetic studies, the small queens found in nests of Myrmica rubra are a distinct, workerless, social parasite exploiting the colonies founded by the larger queens ${ }^{33}$. The subsequent loss of the worker caste in these social parasites might be a byproduct of the strong selection on queens to reduce their size to take advantage of the host caste-determination system. This would allow parasite larvae to develop into sexuals with less food than is required to produce host workers ${ }^{34-36}$.

\section{Queen turnover and kin structure of colonies}

Most theoretical and empirical studies of kin conflict in social insect colonies do not explicitly consider the possibility of queen turnover and intraspecific parasitism. For example, numerous studies have investigated queen-worker conflict over sex ratio in ants, with the aim of testing kin selection and sex-ratio theory ${ }^{2,3,37}$. Where colonies vary in their kin structure, theory predicts that workers produce the sex to which they are more related, compared with the population average ${ }^{38}$. Thus, workers should specialize in queen production in colonies headed by a single queen and on male production in colonies headed by multiple related queens. 
Several studies have shown that colony sex ratios are associated with queen number or worker-worker relatedness, as predicted by theory ${ }^{37,39}$. However, the assumption that actual queen number or worker-worker relatedness are correlated with relatedness asymmetry (the relative relatedness of workers to the male and female brood) need not be true if queen turnover is common. This is because relatedness asymmetry is predicted to correlate with queen number and worker-worker relatedness only if the same queens contribute to the production of workers, and the brood raised by the workers. A recent study in the ant Formica exsecta showed that colonies with low worker-worker relatedness produce mostly males, whereas colonies with high worker-worker relatedness produce mostly females, in apparent accordance with theory. However, there was no correlation between the sex produced by colonies and the relative relatedness of workers to male and female brood ${ }^{40}$. The lack of a correlation between worker-worker relatedness and relatedness asymmetry probably stems from queen turnover being common in this species (with the effect that workers and the brood are not the offspring of the same set of queens).

Similarly, the possible occurrence of queen turnover should always be considered when the existence of potential conflict is assumed from indirect information on the breeding structure. For example, the inferred number of mates per queen (which is expected to influence many potential conflicts within the colonies ${ }^{41,42}$ ) is frequently assessed indirectly from the genetic diversity of the brood and/or workers in the colony. If queen turnover occurred recently, such indirect methods might lead to false conclusions on the breeding structure and inferred potential conflicts. For example, if the possibility of a recent queen turnover is not considered, the distribution of worker genotypes might lead to the wrong conclusion that queens are multiply mated in a monogynous colony.

\section{Conclusion and perspectives}

The previously underestimated diversity of ant reproductive life histories might be of considerable importance for evolutionary biology and, in particular, for studies of social evolution in ants. As yet, most cases of alternative reproductive tactics in animals have been reported from males $^{22}$, and little is known about this phenomenon in females. Ants are an interesting system to investigate the ultimate and proximate causes of female polymorphism ${ }^{23}$. Because morphology and reproductive strategies are presumably closely linked, variation in the frequency of alternative queen phenotypes between different collecting sites might allow us to investigate which ecological factors determine the success of different tactics, and which types of selection are involved.

The replacement of old queens by young, unrelated queens, in both polygynous and monogynous species, raises important questions for social insect researchers. How frequently do colonies recruit related versus unrelated queens? Are unrelated queens frequently able to enter and displace the breeding queen in monogynous colonies? If so, how do these queens circumvent the mechanisms of recognition that generally allow workers to effectively exclude non-nestmates? The recent development of highly polymorphic genetic markers and methods to determine the precise genetic relationship between group members $^{43}$ provide unique opportunities to investigate these questions. Another important aspect is how frequently does queen replacement occur in other social insects. Usurpation of freshly initiated nests is well known from annual social wasps and bees ${ }^{44}$. To infiltrate a dying annual nest later in the season is certainly not adaptive, but colony takeover by unrelated queens might occur in mature societies of some perennial species.

Finally, the finding that the breeding structure of ant colonies is more labile than had been thought previously, calls for an integration of both life history and kin-selection perspectives in the study of social evolution and kin conflict. The first step in this direction has already been taken following the realization that the dynamics of conflict vary over the lifetime of colonies: for example, with different conflicts occurring in colonies containing small numbers versus those with large numbers of workers ${ }^{45}$. It is not only worker number but also the identity and number of reproductive individuals that varies over time, which adds one more level of complexity to the study of social insects. This complexity will open the door to exciting new possibilities of incorporating kin-selection theory into life history models; thus providing a comprehensive understanding of the interplay between colony ontogeny and the dynamics of conflict in insect societies.

\section{Acknowledgements}

We thank A.F.G. Bourke, M. Chapuisat, F.L.W. Ratnieks and three anonymous referees for their comments. Funding was obtained through the research network 'Integrated studies of the economy of insect societies', financed by the European Commission via the Human Potential Programme, and from the Swiss National Science Foundation to L.K.

\section{References}

1 Herbers, J.M. (1993) Ecological determinants of queen number in ants: In Queen Number and Sociality in Insects (Keller, L., ed.), pp. 262-293, Oxford University Press

2 Crozier, R.H. and Pamilo, P. (1996) Evolution of Social Insect Colonies, Oxford University Press

3 Bourke, A.F.G. and Franks, N.R. (1995) Social Evolution in Ants, Princeton University Press

4 Keller, L. (1995) Social life: the paradox of multiple-queen colonies. Trends Ecol. Evol. 10, 355-360

5 Ortius, D. and Heinze, J. (1995) Dynamics and consequences of hierarchy formation in the ant Leptothorax sp. A. Ethology 99, 223-233

6 Boomsma, J.J. and Ratnieks, F.L.W. (1996) Paternity in social Hymenoptera. Phil. Trans. R. Soc. London Ser. B 351, 697-704

7 Bourke, A.F.G. et al. (1997) Parentage, reproductive skew and queen turnover in a multiple-queen ant analysed with microsatellites. Proc. $R$. Soc. London Ser. B 264, 277-283

8 Pearson, B. et al. (1997) Temporal changes in the relationship between observed and expected sex-investment frequencies, social structure and intraspecific parasitism in Leptothorax tuberum (Formicidae). Biol. J. Linn. Soc. 61, 515-536

9 Evans, J.D. (1996) Queen longevity, queen adoption, and posthumous indirect fitness in the facultatively polygynous ant Myrmica tahoensis. Behav. Ecol. Sociobiol. 39, 275-284

10 Keller, L. and Genoud, M. (1997) Extraordinary lifespans in ants: a test of evolutionary theories of ageing. Nature 389, 958-960

11 Hölldobler, B. and Wilson, E.O. (1990) The Ants, Harvard University Press

12 Stille, M. and Stille, B. (1992) Intra- and inter-nest variation in mitochondrial DNA in the polygynous ant Leptothorax acervorum (Hymenoptera; Formicidae). Insectes Soc. 39, 335-340

13 Carew, M.E. et al. (1997) Polygyny via unrelated queens indicated by mitochondrial DNA variation in the Australian meat ant Iridomyrmex purpureus. Insectes Soc. 44, 7-14

14 Tay, W.T. et al. (1997) Migration between nests in the Australian aridzone ant Rhytidoponera sp. 12 revealed by DGGE analyses of mitochondrial DNA. Mol. Ecol. 6, 403-411

15 Bernasconi, G. and Strassmann, J.E. (1999) Cooperation among unrelated individuals: the ant foundress case. Trends Ecol. Evol. 14 $477-482$ 
16 Gadau, J. et al. (1998) Oligogyny by unrelated queens in the carpenter ant, Camponotus ligniperdus. Behav. Ecol. Sociobiol. 44, 23-33

17 Foitzik, S. and Heinze, J. (1998) Nest site limitation and colony takeover in the ant Leptothorax nylanderi. Behav. Ecol. 9, 367-375

18 Oster, G.F. and Wilson, E.O. (1978) Caste and Ecology in Social Insects, Princeton University Press

19 Mclnnes, D.A. and Tschinkel, W.R. (1995) Queen dimorphism and reproductive strategies in the fire ant Solenopsis geminata (Hymenoptera: Formicidae). Behav. Ecol. Sociobiol. 36, 367-375

20 Nonacs, P. (1988) Queen number in colonies of social hymenoptera as a kin-selected adaptation. Evolution 42, 566-580

21 DeHeer, C.J. and Tschinkel, W.R. (1998) The success of alternative reproductive tactics in monogyne populations of the ant Solenopsis invicta: significance for transitions in social organization. Behav. Ecol. $8,130-135$

22 Gross, M.R. (1996) Alternative reproductive strategies and tactics: diversity within sexes. Trends Ecol. Evol. 11, 92-98

23 Rüppell, O. and Heinze, J. (1999) Alternative reproductive tactics in females: the case of size polymorphism in winged ant queens. Insectes Soc. 46, 6-17

24 Stille, M. (1996) Queen/worker thorax volume ratios and nest-founding strategies in ants. Oecologia 105, 87-97

25 Bolton, B. (1986) Apterous females and shift of dispersal strategy in the Monomorium salomonis-group (Hymenoptera: Formicidae). J. Nat. Hist. 20, 267-272

26 Heinze, J. and Buschinger, A. (1989) Queen polymorphism in Leptothorax sp. A: its genetic and ecological background (Hymenoptera: Formicidae). Insectes Soc. 36, 139-155

27 Yamauchi, K. et al. (1991) Secondary polygyny by inbred wingless sexuals in the dolichoderine ant Technomyrmex albipes. Behav. Ecol. Sociobiol. 29, 313-319

28 Ohkawara, K. et al. (1993) Production and reproductive function of intercastes in Myrmecina graminicola nipponica colonies (Hymenoptera: Formicidae). Insectes Soc. 40, 1-10

29 Winter, U. and Buschinger, A. (1986) Genetically mediated queen polymorphism and caste determination in the slavemaking ant Harpagoxenus sublaevis (Hymenoptera: Formicidae). Entomol. Gen. $11,125-137$

30 DeHeer, C.J. et al. (1999) Queen dispersal strategies in the multiple-queen form of the fire ant Solenopsis invicta. Am. Nat. 153, $660-675$

31 Buschinger, A. (1990) Sympatric speciation and radiative evolution of socially parasitic ants - heretic hypotheses and their factual background. Z. Zool. Syst. Evol. Forsch. 28, 241-260

32 Bourke, A.F.G. and Franks, N.R. (1991) Alternative adaptations, sympatric speciation and the evolution of parasitic, inquiline ants. Biol. J. Linn. Soc. 43, 157-178

\section{Organizing a meeting?}

Each month TREE publishes brief details of forth-

coming meetings. If you would like your conference

or symposium to have a free entry in TREE's

Meetings Diary, please send the details to:

The Editor, Trends in Ecology \& Evolution,

84 Theobald's Road, London, UK WC1X 8RR

(e-mail: tree@current-trends.com). If you wish us to

publish details of courses or a longer

announcement, please contact Classified at the same address.
33 Pearson, B. and Child, A.R. (1980) The distribution of an esterase polymorphism in macrogynes and microgynes of Myrmica rubra Latreille. Evolution 34, 105-109

34 Nonacs, P. and Tobin, J.E. (1992) Selfish larvae: development and the evolution of parasitic behavior in the Hymenoptera. Evolution 46, 1605-1620

35 Bourke, A.F.G. and Ratnieks, F.L.W. (1999) Kin conflict over caste determination in social Hymenoptera. Behav. Ecol. Sociobiol. 46, 287-297

36 Aron, S. et al. (1999) Evolution of social parasitism in ants: size of sexuals, sex ratio and mechanisms of caste determination. Proc. $R$. Soc. London Ser. B 266, 173-177

37 Queller, D.C. and Strassmann, J.E. (1998) Kin selection and social insects. BioScience 48, 165-175

38 Boomsma, J.J. and Grafen, A. (1990) Intraspecific variation in ant sex ratios and the Trivers-Hare hypothesis. Evolution 44, 1026-1034

39 Chapuisat, M. and Keller, L. (1999) Testing kin selection with sex allocation data in eusocial Hymenoptera. Heredity 82, 473-478

40 Brown, W.L. and Keller, L. (2000) Colony sex ratios vary with queen number but not relatedness asymmetry in the ant Formica exsecta. Proc. R. Soc. London Ser. B 267, 1751-1757

41 Ratnieks, F.L.W. and Reeve, H.K. (1992) Conflict in single-queen Hymenoptera societies: the structure of conflict and processes that reduce conflict in advanced eusocial species. J. Theor. Biol. 158, 33-65

42 Keller, L. and Reeve, H.K. (1999) Dynamics of conflicts within insect societies; In Levels of Selection in Evolution (Keller, L., ed.), pp. 153-175, Princeton University Press

43 Goodnight, K.F. and Queller, D.C. (1999) Computer software for performing likelihood tests of pedigree relationship using genetic markers. Mol. Ecol. 8, 1231-1234

44 Field, J. (1992) Intraspecific parasitism as an alternative reproductive tactic in nest-building wasps and bees. Biol. Rev. 67, 79-126

45 Bourke, A.F.G. (1999) Colony size, social complexity and reproductive conflict in social insects. J. Evol. Biol. 12, 245-257

46 Hagen, R.H. et al. (1988) Genetic relatedness among co-foundresses of two desert ants, Veromessor pergandei and Acromyrmex versicolor. Psyche 95, 191-201

47 Goodisman, M.A.D. and Ross, K.G. (1998) A test of queen recruitment models using nuclear and mitochondrial markers in the fire ant Solenopsis invicta. Evolution 52, 1416-1422

48 Trunzer, B. et al. (1998) Cooperative colony founding and experimenta primary polygyny in the ponerine ant Pachycondyla villosa. Insectes Soc. 45, 267-276

49 Heinze, J. and Tsuji, K. (1995) Ant reproductive strategies. Res. Popul. Ecol. 37, 135-149

50 Heinze, J. (1989) Leptothorax wilsoni n. sp., a new parasitic ant from Eastern North America (Hymenoptera: Formicidae). Psyche 96, 49-61

\section{Do you want to reproduce material from TREE?}

This publication and the individual publications contained in it are protected by the copyright of Elsevier Science. Except as outlined in the terms and conditions (see p. iv), no part of

Trends in Ecology \& Evolution may be reproduced, either in print or in electronic form, without written permission from Elsevier Science.

Please send any permission requests to:

Elsevier Science Ltd
PO Box 800
Oxford
UK OX5 1DX

